\title{
SkagBoys (2014). Irvine Welsh. Editorial Anagrama, Barcelona.
}

\author{
Por Julio Hevia \\ (Universidad de Lima)
}

pelando a una noción de plena actualidad cabe calificar el
relato de Irvine Welsh como una auténtica y contundente
precuela de aquel Trainspoitting cuya versión fílmica tanto impacto suscitara décadas atrás. Bajo el marco de una Escocia azotada por rigurosas medidas de austeridad, el autor vuelve sobre las andanzas de sus cinco entrañables personajes (Sick Boy, Spud, Renton, Diane y Beggie) con el claro propósito de reivindicar un estilo de subsistencia al que estos debieron aferrarse, he allí el perfil de buscón adolescente devenido usuario eventual de heroína para luego encarnar la figura del yonkee cadavérico. El retrato de época que nos extiende Welsh opera, cual vaivén, de afuera hacia adentro y de adentro hacia afuera, mostrando las dos caras del guante que azotaba, durante la década del 80 , a unas comunidades obreras signadas por la desocupación laboral y una progresiva desesperanza ante el futuro cercano.

Es de notar en el relato la fuerza con que cada contexto familiar marca, a fuego lento, las pequeñas grandes decisiones que arrojan a nuestros personajes en el submundo de las fugas intravenosas y las inmanejables adicciones. Un rápida revisión del exiguo escenario en el que cada uno de ellos se mueve irá a incluir deudas por arrendamiento que mal puede salvar el grupo parental, expectativas de mejora económica que lindan con la alucinación en algunos de sus miembros o abandonos maritales y alcoholizaciones que nada remedian y todo lo agravan. $Y$ es que tampoco notamos gran diferencia, hay que decirlo, entre los tugurios donde se refugian y abandonan los yonkees de la novela y aquella pauperización que, cual máquina trituradora de las relaciones familiares, disuelve cualquier intento de conservar los afectos convivenciales o el esforzado afán de mantener la mínima armonía en casa.

La historia certifica que los paraísos entreabiertos por la droga activan, en simultáneo, una promesa y una trampa, una liberación y un claustro, un paréntesis extendido hoy que, a duras penas, posterga la recaída del mañana. Hablamos de una militancia ciega, postura 
negadora de las vicisitudes mundanas que mal podría tomar en cuenta, claro está, los irreversibles costos que ese mismo abandono exige.

Una cosa nos va quedando clara con el desarrollo del texto: que para un orden de cosas donde la voluntad opera cual comparsa pasiva o se constituye en vil cómplice de los propios apetitos, no hay más opción que seguir inyectándose y suscribirse a esa tenaz dependencia. Inextricablemente adheridos como están, en dicha servidumbre, las mentes y los cuerpos, poco importará distinguir allí las razones de los pretextos, la fisiología biológicamente ritmada de los más imperiosos y fantasmales deseos.

En medio de un sinfín de recorridos y rutinas mil veces trazadas por los personajes llama la atención, eso sí, el aliento que precisan tomar para reinsertarse en la sombría realidad de sus hogares, para confrontarse a la mirada de sus allegados y recordar, una vez más, que es en ese mismo radio donde radica el problema del que intentan librarse mediante el denominado "jaco". En paralelo, Welsh trabaja el modo en que hombres y mujeres se van abismando en tal fragor y polarizando sus trayectorias. Así pues, los hombres parecen todavía dispuestos a pagar por el sexo o a trocarlo por droga, a diferencia de las mujeres que, según una historia archiconocida y no poco lamentada, negocian con sexo su propia adicción, se prostituyen o son prostituidas sin remedio.

Aunque unos y otras luchan por no sumergirse del todo en el fango, valga invocar cuánto el manto depresivo que una vida poco aleccionadora y atiborrada de accidentes abastece las requeridas justificaciones para volver a hincarse las venas. Hacia los capítulos finales, el proceso de la forzosa rehabilitación en que se ven insertos algunos de los protagonistas da cuenta de una lógica testimonial particularmente reveladora. Desfila ante el lector el espectro de facetas por las que el adicto atraviesa, o sea, la pura y dura confrontación con el síndrome de abstinencia, el conocido boicot a todo apoyo terapéutico " $y$, alternadamente, el convencimiento gradual de que -contra viento y marea- quizá sea posible recuperar la salud extraviada". Caídas y levantamientos que van a gestar un plan obsesamente atesorado: oxigenar el cuerpo como para justificar la dada de alta y, sobre la marcha, reinsertarse en el mundo del consumo de heroína bajo el supuesto de hacerlo en dosis más espaciadas y con precauciones no observadas anteriormente.

En buena cuenta, Skagboys es un relato frontal y trepidante sobre la agudización de las distancias abonadas entre heroinómanos y el 
circuito de sus allegados: distancias que se abonan entre un mañana cada vez más remoto e inalcanzable y un presente harto requerido de los consabidos y engañosos placebos; o las que se yerguen, como un cerco, entre el proyecto amoroso con una pareja claramente dispuesta y la siniestra e inexplicable dependencia de la heroína; de repente las que separan a un adulto, mal que bien habituado a esperar y a resignarse en esa espera, de la apremiante expectativa que surca el día a día del joven desocupado, el mismo que cree encontrar la vía más radical de suprimirlo todo y de aferrarse a ella cuantas veces se juzgue necesario.

En las últimas páginas un comentario nos habla de la ingenuidad de vengarse del mundo en el propio cuerpo, máxime durante una coyuntura en la que ese mismo mundo usufructúa y prescinde, con espantosa facilidad, de todos aquellos que optan por inmolarse en el camino. Un guiño esperanzador propone dividir las aguas entre aquellos que, definitivamente, se hunden en el vértigo del consumo y otros personajes que, en medio de su avidez por experimentar, no limitan su destino a tal causa; es el caso de los que aún conservan intactos ciertos recursos que se yerguen contra el arrastre inercial de la marea adictiva; por excepcionales que fueran tales casos, se trata de gente que saca fuerzas de flaqueza y, sin olvidar los costos de su caída y recuperación, encuentran otras razones para enrumbar el camino.

Dicho en pocas palabras, el texto de Welsh justifica plenamente el aura del que viene precedido y abunda en razones que tornan justificada y harto ilustrativa su lectura. 